\title{
Pengaruh Model Team Games Tournament Berbantuan Media Lingkungan Terhadap Kompetensi Pengetahuan IPA
}

\author{
Ni Kadek Surasmini Adi Candra Dewi*, I Ketut Ardana², Ni Nyoman Ganing3
}

123 Program Studi Pendidikan Guru Sekolah Dasar Universitas Pendidikan Ganesha

\begin{abstract}
Abstrak
Penelitian ini bertujuan untuk mengkaji pengaruh model team games tournament berbantuan media lingkungan terhadap kompetensi pengetahuan IPA. Jenis penelitian ini quasi eksperiment dengan menggunakan rancangan nonequivalent pretest-posttes control group design. Populasi penelitian ini yaitu seluruh siswa kelas IV SD Gugus Untung Surapati, dengan jumlah 206 siswa. Sampel ditentukan dengan teknik random sampling kelas IV SDN 4 Sumerta sebagai kelas eksperimen dan SDN 11 Sumerta sebagai kelas kontrol, dengan jumlah sampel 74 siswa. Metode pengumpulan data dalam penelitian ini menggunakan metode tes dengan instrumen tes objektif pilihan ganda. Data dianalisis menggunakan uji t. Instrumen pengumpulan data yang digunakan berupa pilihan ganda yang kemudian dianalisis dengan analisis uji-t polled varian, data yang dianalisis pada penelitian ini yaitu data posttest yang merupakan kompetensi pengetahuan IPA siswa, namun terlebih dahulu dilakukan uji normalitas menggunakan kolmogorov-smirnov dan homogenitas dengan rumus fisher. Berdasarkan analisis uji t dengan $(\mathrm{dk}=36+38=74-2=72)$ pada taraf signifikan $5 \%$ diperoleh thitung $=5.750$ dan untuk tabel $=1.993$. Dengan demikian nilai thitung $=5.750>$ tabel $=1.993$ maka Ho ditolak dan Ha diterima. Dengan demikian, terdapat perbedaan yang signifikan kompetensi pengetahuan IPA antara kelompok siswa yang dibelajarkan melalui model pembelajaran Team Games tournament berbantuan media lingkungan dengan kelompok siswa yang dibelajarkan melalui pembelajaran konvensional pada siswa kelas IV SD Gugus Untung Surapati tahun ajaran 2019/2020.
\end{abstract}

Kata Kunci:

Team Games

Tournament, media

lingkungan,

kompetensi

pengetahuan IPA

\begin{abstract}
This research is aimed to know the impact of Team Games Tournament model assisted with surroundings media on the IPA (natural science) competency. This is a quasi-experiment that used nonequivalent pretest-posttest control group design. The research population was all of grade IV students at SD Gugus Untung Surapati with 206 students in total. Samples were taken through random sampling, with grade IV students at SD N 4 Sumerta as experimental group, and SD N 11 Sumerta as control group, all totalling 74 students. Data were collected by test, with multiple-choices test instrument, and analyzed with t-test. Data were collected with multiple choices test, analyzed with polled variant t-test. The data analyzed were posttest result of students' IPA competency, that were previously tested for normality using Kolmogorov-smirnov and, for homogeneity using Fischer formula. The t-test resulted in $(\mathrm{dk}=36+38=74-2=72)$ at $5 \%$ significance level, $\mathrm{t}_{\text {test }} \mathrm{o}=5.750$ and $\mathrm{t}_{\text {table }}=1.993$ Thus, as value of $t_{\text {test }} \mathrm{o}=5.750>\mathrm{t}_{\text {table }}=1.993$, Ho is rejected and Ha accepted. It is concluded that there is a significant difference on students' IPA competency between the groups that were learned with Team Games Tournament model assisted with surroundings media and the group that were learned by using conventional media, on grade IV students at SD Gugus Untung Surapati academic year 2019/2020.
\end{abstract}

Keywords:

Team Games

Tournament, surroundings media, science knowledge competency

\footnotetext{
* Corresponding author. 


\section{PENDAHULUAN}

Pendidikan merupakan salah satu sarana yang sangat penting dalam meningkatkan kualitas sumber daya manusia (SDM) dalam menjamin kelangsungan pembangunan. Kemampuan-kemampuan siswa perlu dikembangkan dalam pendidikan dapat berjalan dengan baik. Oleh karenanya, pemerintah Indonesia melakukan berbagai upaya untuk meningkatkan kualitas pendidikan. Perubahan kurikulum pembelajaran berawal kurikulum KTSP menjadi kurikulum 2013 dimana dalam kurikulum 2013 proses pembelajarannya adalah berpusat pada siswa, menuntut guru lebih kreatif dan inovatif dalam merancang kegiatan pembelajaran yang melibatkan peran aktif siswa. Pembelajaran yang berlangsung seharus menumbuhkan keaktifan siswa dari segi bertanya, mempertanyakan serta mengemukakan pendapat.

Dengan adanya perubahan tersebut juga dapat berubahnya komponen pendidikan dalam berbagai standar yakni standar isi, proses, serta kompetensi lulusan. Satu diantara komponen nilai yang didapatkan oleh siswa tergantung dari siswa itu sendiri. Mata pelajaran utama dalam penelitian ini adalah Ilmu Pengetahuan Alam (IPA). Menurut Samatowa (2016) dalam bahasa inggris ilmu pengetahuan alam disebut sebagai natural science. Ilmu pengetahuan alam yang disingkat IPA memiliki istilah tersendiri yakni pendidikan sains. Baktini (2019) menyatakan bahwa IPA merupakan ilmu yang mempelajari alam, baik berupa pengamatan dengan mengikuti prosedur yang telah ditentukan, kemudian dijelaskan berdasarkan penalaran dan kemudian menyimpulkannya. Sejalan dengan hal tersebut Agustini (2014) berpendapat bahwa Ilmu Pengetahuan Alam (IPA) yang sering disebut dengan pendidikan sains merupakan salah satu mata pelajaran pokok dalam kurikulum pendidikan di Indonesia, termasuk pada jenjang sekolah dasar.

Berkaitan dengan pembelajaran IPA yang bermakna di sekolah dasar, hendaknya seorang guru memperkenalkan lingkungan dan peristiwa yang sering dialami oleh siswa dalam kehidupan sehari-hari. Hal ini dapat meningkatkan daya tarik siswa dalam belajar IPA. Selain itu, penerapan model atau metode yang sesuai juga dapat memaksimalkan proses pembelajaran yang terjadi. Pembelajaran pun dapat berpengaruh positif terhadap hasil yang dicapai siswa. Seperti yang dikemukakan oleh Susanto (2012) proses pembelajaran IPA yang tepat diharapkan dapat membentuk keterampilan maupun kemampuan berpikir dalam memecahkan masalah dalam kehidupan sehari-hari. Artinya, proses tersebut menuntut guru memberikan kesempatan kepada siswa menemukan, menguasai suatu konsep dengan tepat, dan menerapkannya dalam kehidupan. Pembelajaran IPA mengarahkan siswa untuk aktif sehingga dapat membantu siswa dalam mendapatkan pemahaman yang lebih dalam mengenai alam disekitarnya.

IPA dibutuhkan dalam kehidupan sehari-hari untuk melengkapi kebutuhan manusia melalui diidentifikasinya suatu pemecahan masalah. Agar tidak berdampak buruk terhahap lingkungan penerapan IPA harus dilaksanakan secara sederhana. Maka dari itu pembelajaran IPA menitikberatkan dalam mengembangkan keterampilan proses serta sikap ilmiah. Karakteristik dari siswa harus diperhatikan untuk memenuhi kebutuhan ketika pembelajaran IPA. Hal tersebut dapat dilihat pada proses pembelajaran sebagian siswa belum mampu berkonsentrasi pada waktu yang relative lama.

Berdasarkan hasil wawancara yang telah dilaksanakan di SD Negeri gugus Untung Surapati bahwa kompetensi pengetahuan IPA siswa masih belum optimal, siswa masih banyak berada di bawah Kriteria Ketuntasan Minimal (KKM) yaitu 74,00. Hal ini terbukti dari pencatatan nilai Penilaian Tengah Semester (PTS) IPA yang dilakukan di SD Negeri Gugus Untung Surapati yaitu dari 204 siswa sebanyak 114 atau $55,8 \%$ belum mencapai mencapai KKM, sedangkan 90 siswa atau $44,2 \%$ sudah mampu mencapai nilai KKM. Siswa yang belum mencapai KKM yang ditentukan tentu dipengaruhi oleh beberapa faktor. (Wahyuni 2014) berpendapat bahwa proses pembelajaran dipengaruhi oleh faktor intrinsik dari siswa dan faktor ekstrinsik yang dipengaruhi dari luar lingkungan sekolah yang termasuk di dalamnya peran guru serta model ataupun metode yang digunakan. Sejalan dengan hal tersebut berdasarkan hasil observasi yang telah dilaksanakan bahwa pembelajaran berlangsung secara pasif. Hal tersebut terjadi karena pembelajaran berpusat pada guru saja, siswa hanya mendengarkan materi yang disampaikan, kemudian menjawab soal yang diberikan. Selain itu guru kurang menggunakan media yang dapat menunjang pembelajaran khususnya muatan materi IPA. Untuk mengatasi hal-hal tersebut, perlu adanya upaya untuk mengubah paradigma lama dengan paradigma pembelajaran baru yaitu dengan menerapkan model-model pembelajaran yang relevan.

Permainan adalah satu dari banyak cara yang dapat membuat belajar siswa lebih menyenangkan. Tentunya permainan yang dibuat pada saat pembelajaran adalah permainan akademik yang mampu meningkatkan motivasi belajar serta memberi rangsangan agar siswa aktif bekerjasama pada saat pembelajaran. Model pembelajaran yang merancang permainan akademik dalam penerapan penerapannya yakni model pembelajaran Team Games Tournament. Menurut Hakim (2017)Model pembelajaran Team Games Tournament adalah salah satu tipe pembelajaran kooperatif dimana didalamnya terdapat komponen pembelajaran yang di kemas dalam bentuk permainan yang terdiri dari kelompok-kelompok siswa yang melakukan turnamen akademik maupun kuis. Dalam model Team Games 
Tournament siswa dapat dibentuk dalam kelompok-kelompok kecil yang terdiri 3 sampai 5 siswa heterogen, baik dalam prestasi akademik, ras, etnis maupun jenis kelamin. Sudamayanto (2014) menyatakan bahwa model pembelajaran TGT merupakan kegiatan pembelajaran yang memberikan kemungkinan kepada siswa untuk mengembangkan pemahaman siswa melalui berbagai kegiatan. Sejalan dengan hal tersebut Kusumaningrum (2014) berpendapat bahwa model pembelajaran kooperatif Teams Games Tournament (TGT), akan mengubah proses pembelajaran yang tadinya berpusat pada guru menjadi pembelajaran yang berpusat pada siswa. Proses pembelajaran yang berpusat pada siswa memberikan kesempatan dan fasilitas untuk membangun sendiri pengetahuannya, sehingga siswa akan memperoleh pemahaman yang mendalam.

Wulandari (2018) mengungkapkan bahwa pada model Team Games Tournament memiliki beberapa tahapan yang harus dilewati pada saat proses belajar pembentukan kelompok hingga siswa bersaing dan berkompetensi antara kelompol satu dengan yang lain yang disajikan dalam suatu games agar proses belajar tidak terasa membosankan. Kegiatan belajar bersama permainan yang dibuat dalam pembelajaran model Team Games Tournament membuat siswa belajar lebih tenang dan tidak tegang di samping itu juga dapat menanamkan rasa bertanggung jawab, kerjasama, bersaing secara sehat, dan terlibatnya proses belajar. Selain menggunakan model, penelitian ini juga menggunakan media pembelajaran. (Setiadi 2019) mengungkapkan media pembelajaran secara umum adalah alat bantu proses belajar mengajar. Segala sesuatu yang dapat dipergunakan untuk merangsang pikiran, perasaan, perhatian dan kemampuan atau ketrampilan pebelajar sehingga dapat mendorong terjadinya proses belajar. Media yang digunakan yaitu media lingkungan. Menurut (Hamzah 2012) generasi muda sangat baik untuk diajak mengetahui faktor apa saja yang berpengaruh dalam turunnya kualitas lingkungan hidup. Lebih lanjut (Hamzah 2012) pada pendidikan anak usia dini sangat baik dalam memberi pemahaman dan kesadaran dari pentingnya menjaga kelestarian lingkungan. (Prameswari 2017) berpendapat bahwa Sumber belajar lingkungan ini akan semakin memperkaya wawasan dan pengetahuan anak. Selain itu, kebenarannya lebih akurat, sebab anak dapat mengalami secara langsung dan dapat mengoptimalkan potensi panca indranya untuk berkomunikasi dengan lingkungan tersebut. Sikap, pengetahuan dan keterampilan yang diperoleh di sekolah dilakukan secara terencana melalui proses pembelajaran dilakukan secara nyata dan dapat diterapkan di lingkungan mereka.

Hal ini didukung oleh hasil penelitian Dantes (2017) yang menemukan bahwa penerapan model pembelajaran kooperatif tipe TGT (Teams Games Tournament) dengan media kartu kata dapat meningkatkan motivasi belajar dan kemampuan membaca permulaan pada siswa kelas II semester II SD No. 2 Penarukan. Selain itu didukung oleh hasil penelitian Japa (2017) bahwa penerapan pembelajaran kontekstual dengan mengintensifkan tutor sebaya dan media lingkungan dalam mata pelajaran IPA pada siswa kelas IV semester II SD No. 4 Selat dapat meningkatkan prestasi belajar siswa yaitu dari kategori sedang menjadi tinggi yaitu dari $67,3 \%$ menjadi $81,7 \%$ yang menunjukkan peningkatan $14,4 \%$. Beserta hasil penelitian yang dilaksanakan oleh (Karini 2020) yang menemukan bahwa terdapat perbedaan yang signifikan siswa yang dibelajarkan menggunakan model pembelajaran TGT (Teams Games Tournament) dengan Seting Lesson Study dengan siswa yang tidak dibelajarkan menggunakan model pembelajaran TGT (Teams Games Tournament) dengan Seting Lesson Study.

Dengan demikian untuk dapat meningkatkan partisipasi siswa agar pembelajaran terasa lebih menyenangkan maka diujikan model yang dapat menunjang proses pembelajaran. Pengujian penelitian tersebut yakni dengan judul "Pengaruh Model Team Games Tournament Berbantuan Media Lingkungan Terhadap Kompetensi Pengetahuan IPA Siswa Kelas IV SD Negeri Gugus Untung Surapati Tahun Ajaran 2019/2020".

\section{METODE}

Rancangan penelitian ini akan dilaksanakan pada semester 2 di kelas IV SD Negeri Gugus Untung Surapati tahun ajaran 2019/2020. Penelitian kuantitatif yang digunakan dalam penelitian ini yaitu dengan jenis eksperimen semu serta menggunakan desain yakni "Non Equivalent Prestest-Posttest Control Group Design" karena tidak memungkinkan mengontrol terhadap segala variabel yang ada maka dari itu tergolong quasi experiment.

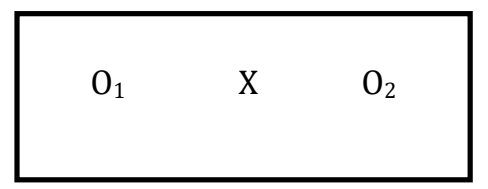

Gambar 1. Desain Penelitian Non Equivalen Pretest-Posttest Control Group Design (Sugiyono 2016) 
Keterangan:

$\mathrm{O}_{1} \quad=$ Pretes pada kelompok eksperimen

$\mathrm{O}_{2} \quad$ Posttes pada kelompok eksperimen

$\mathrm{O}_{3} \quad=$ Pretes pada kelompok kontrol

$\mathrm{O}_{4} \quad=$ Posttes pada kelompok kontrol

$\mathrm{X} \quad$ = Perlakuan pada kelompok eksperimen

- $\quad$ = Tanpa perlakuan pada kelompok kontrol

Menurut Sugiyono (2016) populasi adalah keseluruhan dari orang yang memiliki suatu ciri khas yang diterapkan oleh peneliti yang hasilnya dianalisis dan kemudian diambil keputusan. Sedangkan sampel merupakan jumlah yang dimiliki populasi itu sendiri karena memiliki jangkauan yang lebih kecil dari keseluruhan populasi (Sugiyono 2016). Terpilih dua kelompok dalam penelitian ini sebagai sampel yang nantinya diperlakukan tidak sama atau berbeda.

Sampel yang digunakan kelompok eksperimen diberi perlakuan khusus yaitu pembelajaran dengan menggunakan model Team Games Tournament berbantuan media lingkungan dan kelompok kontrol diberi perlakuan seperti biasanya yaitu menggunakan pembelajaran konvensional. Sampel yang digunakan dalam penelitian ini adalah teknik sampling acak (random sampling). Menurut Agung (2014) sampling random merupakan teknik dengan cara mencampur subjek-subjek yang terdapat pada populasi sehingga semua subjek dianggap sama, semua subjek mendapat hak yang sama untuk dipilih menjadi anggota sampel. Dalam menentukan sampel cara yang digunakan adalah dengan pengundian. Teknik penyetaraan antara kelompok eksperimen dan kelompok kontrol menggunakan teknik matching.

Matching adalah suatu teknik yang digunakan untuk menyeragamkan kelompok yang dijadikan sampel dengan memasangkan atau menjodohkan anggota-anggota kelompok dengan memilih satu anggota secara random kemudian dicari pasangannya. Dalam penelitian ini digunakan nilai pretest untuk memasangkan anggota-anggota kelompok yang dijadikan sampel. Jika ada subjek yang tidak mendapat pasangan yang setara maka siswa harus dihilangkan dari sampel penelitian, tetapi tetap dilibatkan dalam eksperimen atau datanya tidak dianalisis agar psikologis siswa tidak terganggu. Setelah dua sampel diketahui setara selanjutnya dilakukan pengundian kembali untuk memilih kelas yang dijadikan kelompok eksperimen dan kelompok kontrol (Darmadi 2014), jadi dalam teknik matching ini masingmasing subyek yang nilai pretest nya mirip akan dipasangkan. Apabila terdapat subyek tidak mendapatkan pasangan maka tidak diikutkan dari penelitian.

Setelah diketahui kedua kelompok setara, kemudian dilaksanakan pengundian kedua untuk menentukan kelas eksperimen dan kelas kontrol. Setelah dilakukan random sampling maka kelas yang terpilih untuk menjadi kelas eksperimen adalah kelas IV di SD Negeri 4 Sumerta sedangkan kelas kontrol adalah kelas IV di SD Negeri 11 Sumerta. Data yang diperlukan dalam penelitiaan ini yaitu data tentang kompetensi pengetahuan IPA siswa. Tes dapat digunakan untuk mengumpulkan data serta digunakan untuk mengukur kompetensi pengetahuan IPA. Instrumen yang digunakan dalam mengumpulkan data kompetensi pengetahuan IPA yaitu tes. Jenis tes yang digunakan yaitu tes objektif dalam bentuk pilihan ganda biasa dengan empat pilihan. Sebelum tes kompetensi pengetahuan digunakan, maka diuji secara empiris melalui uji validitas, daya beda, indeks kesukaran dan reliabilitas.

Sugiyono (2016) menyatakan bahwa suatu ukuran yang menunjukkan derajad ketepatan antar data yang terjadi pada objek penelitian dengan daya yang dapat dilaporkan oleh peneliti disebut validitas. Pada penelitian ini, Instrumen yang telah dibuat dan telah dikonsultasi selanjutnya dilakukan kegiatan uji coba. Untuk mengukur butir tes yang berbentuk pilihan ganda dapat menggunakan rumus koefesien korelasi point biserial $\left(\mathrm{r}_{\mathrm{pbi}}\right)$. Tes hasil belajar IPA tergolong tes yang bersifat dikotomi karena merupakan tes objektif. Uji validitas butir yang dilakukan yaitu dengan menguji cobakan Instrumen dengan sebanyak 50 butir soal. Dengan taraf $5 \%$ diperoleh $r_{\text {tabel }}=0,334$. Berdasarkan perhitungan uji validitas butir, diperoleh yang valid berjumlah 36 butir soal dan yang tidak valid berjumlah 14 butir soal dari 50 butir soal.

Untuk mengetahui soal dalam membedakan siswa yang tergolong mampu menjawab soal dan siswa yang tergolong kurang mampu menjawab soal maka diperlukan uji daya beda. Menurut (Arikunto 2018) siswa yang berkemampuan tinggi dan siswa yang berkemampuan rendah dapat dibedakan dengan daya pembeda soal yang berupa angka dan disebut sebagai indeks deskriminasi (D). Dalam penentuan kelas atas dan kelas bawah masing-masing diambil 50\% dari total sampel karena kurang dari 100 (Arikunto 2018). Pengurutan skor tiap testi dari yang tertinggi sampai terendah adalah cara untuk menentukan kelompok atas serta bawah. Berdasarkan hasil pengujian daya pembeda diperoleh sembilan butir soal dengan kriteria baik, 25 butir soal dengan kriteria cukup baik, 3 tiga butir soal dengan kriteria kurang.

Soal yang baik adalah soal yang tidak terlalu mudah atau sukar. Pemikiran siswa tidak akan terangsang jika soal yang diberikan sangat mudah. Menurut Agung (2014) tingkat kesukaran butir tes adalah bilangan yang menunjukan banyaknya siswa yang bisa menjawab soal tersebut.Angka yang 
menentukan sulit maupun mudahya soal disebut sebagai indeks kesukaran yang memiliki kisaran antara 0,00-1,00. IK yang mendekati 0,00 artinya soal tersebut termasuk dalam kriteria sukar, sedangkan jika mendekati 1,00 maka soal tersebut termasuk dalam kriteria mudah (Arikunto 2016). Berdasarkan kriteria penilaian yang ditetapkan, maka diperoleh tingkat kesukaran butir tes yaitu dengan kriteria mudah 4 butir soal, kriteria sedang 30 butir soal, kriteria sukar 2 butir soal. Untuk tingkat kesukaran perangkat tes yaitu 0,579 dengan kriteria sedang.

Apabila suatu tes mampu memberikan hasil yang tetap dan tidak berubah maka bisa dikatakan tes tersebut memiliki tingkat reliabilitas yang tinggi (Arikunto 2018). Uji reliabilitas dilakukan terhadap butir soal yang valid saja. Uji reliabilitas tes yang bersifat dikotomi ditentukan dengan rumus Kuder Richardson 20 (KR-20). Kriteria yang digunakan untuk menentukan butir soal yang reliabel adalah jika koefisien reliabilitas yang didapat dari perhitungan lebih besar daripada koefisien yang terdapat pada tabel harga kritis dari $r_{\text {tabel }}\left(r_{11}>r_{\text {tabel }}\right)$, maka tes tergolong reliabel. Untuk menentukan tes reliabel atau tidak reliabel maka dibandingkan dengan 0,70. Berdasarkan hasil analisis uji reliabilitas, diperoleh nilai $r_{11}$ sebesar 0.892. Sehingga $r_{11}$ lebih besar dari $r_{\text {tabel }}(0,892>0,70)$. Dengan demikian tes kompetensi pengetahuan IPA siswa tergolong reliabel. Maka reliabilitas akan dianalisi dengan menggunakan rumus Kuder Richardson 20. Dari 36 butir soal yang dinyatakan valid maka diperoleh $r_{11}=0,892>0,70$ artinya bahwa soal tes pilihan ganda pada penelitian ini tergolong reliable.

Sugiyono (2016) mengungkapkan bahwa untuk menganalisis data sampel dan hasilnya diberlakukan untuk populasi menggunakan teknik statistika yaitu statistika inferensial. Teknik pengambilan sampel populasi itu dilakukan secara random dan statistika ini cocok digunakan apabila sampel diambil dari populasi yang benar. Sebelum melakukan uji hipotesis terlebih dahulu melakukan uji prasyarat analisi yaitu Uji Normalitas sebaran data dan Uji Homogenitas Varians.

\section{ANALISIS DAN PEMBAHASAN}

Deskripsi data kompetensi pengetahuan IPA dalam penelitian ini membahas tentang nilai ratarata (mean), standar deviasi dan varians dari data hasil posttest yang telah diberikan pada kelompok eksperimen dan kelompok kontrol. Data yang dianalisis dalam penelitian ini adalah data hasil posttest kompetensi pengetahuan IPA siswa kelas IV. Adapun deskripsi data kompetensi pengetahuan IPA dari masing-masing kelompok siswa yaitu sebagai berikut.

Siswa kelas IV SD Negeri 4 Sumerta yang berjumlah 36 siswa yang dibelajarkan melalui model pembelajaran Team Games Tournament berbantuan media lingkungan adalah kelompok eksperimen dalam penelitian ini. Pada awal penelitian siswa diberikan pretest, kemudian siswa diberikan perlakuan berupa pembelajaran dengan menggunakan model Team Games Tournament berbantuan media lingkungan sebanyak 6 kali pertemuan dan diakhir penelitian siswa diberikan posttest. Data pretest dan posttest kemudian diolah menjadi data normalisasi eksperimen untuk mendapat kompetensi pengetahuan IPA. Berikut ini adalah data normalisasi kelompok eksperimen yang disajikan pada tabel 1.

Tabel 1.Distribusi Frekuensi Bergolong Data Kelompok Eksperimen

\begin{tabular}{lcr}
\hline Interval Kelas & Titik Tengah & Frekuensi (\%) \\
\hline $63-67$ & 65 & 1 \\
$68-72$ & 70 & 1 \\
$73-77$ & 75 & 3 \\
$78-82$ & 80 & 8 \\
$83-87$ & 85 & 13 \\
$88-92$ & 90 & 5 \\
$93-97$ & 95 & 5 \\
\hline Jumlah & & 36 \\
\hline
\end{tabular}

Berdasarkan tabel yang telah dipaparkan, selanjutnya data disajikan secara deskriptif melalui statistika deskriptif dan dalam bentuk tabel distribusi frekuensi bergolong, sebagai berikut. 
Tabel 2. Distribusi Frekuensi Bergolong Data Kelompok Eksperimen

\begin{tabular}{lcr}
\hline Interval Kelas & Titik Tengah & Frekuensi \\
\hline $63-67$ & 65 & 1 \\
$68-72$ & 70 & 1 \\
$73-77$ & 75 & 3 \\
$78-82$ & 80 & 8 \\
$83-87$ & 85 & 13 \\
$88-92$ & 90 & 5 \\
$93-97$ & 95 & 5 \\
\hline
\end{tabular}

Berdasarkan tabel 02 terdapat sebanyak satu orang siswa yang memperoleh skor pada interval kelas 63 - 67 dan 68 - 72. Terdapat sebanyak tiga orang siswa yang memperoleh skor pada interval kelas 73 - 77. Terdapat sebanyak delapan orang siswa yang mendapatkan skor pada interval kelas 78 - 82 . Terdapat sebanyak 13 orang siswa yang memperoleh skor pada interval kelas 83 - 87. Terdapat sebanyak lima orang siswa yang mendapatkan skor pada interval kelas 88 - 92 dan 93 - 97.

Siswa kelas IV SD Negeri 11 Sumerta yang berjumlah 38 siswa, yang dibelajarkan melalui pembelajaran konvensional adalah kelompok eksperimen dalam penelitian ini. Pada awal penelitian siswa diberikan pretest, kemudian siswa diberikan pembelajaran konvensional sebanyak 6 kali pertemuan dan diakhir penelitian siswa diberikan posttest. Untuk mendapatkan data kompetensi pengetahuan IPA, data pretest dan posttest kemudian diolah menjadi data uji normalisasi. Berikut ini adalah data normalisasi kelompok kontrol yang disajikan pada tabel 3.

Tabel 3. Distribusi Frekuensi Bergolong Data Kelompok Kontrol

\begin{tabular}{lcr}
\hline Interval Kelas & Titik Tengah & Frekuensi (\%) \\
\hline $57-61$ & 59 & 5 \\
$62-66$ & 64 & 9 \\
$67-71$ & 69 & 3 \\
$72-76$ & 74 & 4 \\
$77-81$ & 79 & 7 \\
$82-86$ & 84 & 10 \\
$87-91$ & 89 & 0 \\
\hline Jumlah & & 38 \\
\hline
\end{tabular}

Berdasarkan tabel yang telah dipaparkan, selanjutnya data disajikan secara deskriptif melalui statistika deskriptif dan dalam bentuk tabel distribusi frekuensi bergolong, sebagai berikut.

Tabel 4. Distribusi Frekuensi Bergolong Data Kelompok Kontrol

\begin{tabular}{lcr}
\hline Interval Kelas & Titik Tengah & Frekuensi \\
\hline $57-61$ & 59 & 5 \\
$62-66$ & 64 & 9 \\
$67-71$ & 69 & 3 \\
$72-76$ & 74 & 4 \\
$77-81$ & 79 & 7 \\
$82-86$ & 84 & 10 \\
$87-91$ & 89 & 0 \\
\hline
\end{tabular}

Berdasarkan tabel 04 terdapat sebanyak lima orang siswa yang memperoleh skor pada interval kelas 57 - 61. Terdapat sebanyak sembilan orang siswa yang mendapat skor pada interval kelas 62 - 66 . Terdapat sebanyak tiga orang siswa yang mendapat skor pada interval kelas 67 - 71. Terdapat sebanyak empat orang siswa yang mendapat skor pada interval kelas $72-76$. Terdapat sebanyak tujuh orang siswa yang mendapat skor pada interval kelas 77 - 81. Terdapat sebanyak 10 orang siswa yang memperoleh skor pada interval kelas 82 - 86 dan tidak terdapat siswa yang memperoleh skor pada interval kelas 87 91. 
Data yang diperoleh dari penelitian ini kemudian dianalisis dengan beberapa tahapan yaitu uji normalitas, uji homogenitas dan uji hipotesis. Berdasarkan hasil uji normalitas kelompok eksperimen, diperoleh nilai $\mathrm{D}_{\text {hitung }}=0,171$ kemudian nilai tersebut dibandingkan dengan tabel Kolmogorov Smirnov $=$ 0,221 . Hal ini menunjukkan bahwa $D_{\text {hitung }}<$ tabel Kolmogorov Smirnov berarti data hasil kompetensi pengetahuan IPA kelompok eksperimen berdistribusi normal. Perhitungan selengkapnya terlampir pada lampiran.Berdasarkan hasil uji normalitas kelompok kontrol, diperoleh nilai $\mathrm{D}_{\text {hitung }}=0,139$ kemudian nilai tersebut dibandingkan dengan tabel Kolmogorov Smirnov $=0,218$. Hal ini menunjukkan bahwa $\mathrm{D}_{\text {hitung }}<$ tabel Kolmogorov Smirnov berarti data hasil kompetensi pengetahuan IPA kelompok kontrol berdistribusi normal.

Setelah dilakukan uji normalitas maka selanjutnya uji Homogenitas varians. Dari hasil analisi, diperoleh $\mathrm{F}_{\text {hitung }}=0.58$ dan $\mathrm{F}_{\text {tabel }}=1.74$ ini berarti $\mathrm{F}_{\text {hitung }}<\mathrm{F}_{\text {tabel }}$. Berdasarkan hasil uji homogenitas varians disimpulkan bahwa data kedua kelompok sampel adalah memiliki varians yang homogen. Dengan demikian uji hipotesis menggunakan uji t dapat dilakukan.

Berdasarkan hasil yang telah diperoleh dari uji normalitas dan uji homogenitas dapat diketahui bahwa data dari kedua sample berdistribusi normal dan memiliki varian yang homogen. Data telah memenuhi uji prasyarat maka tahap selanjutnya yaitu uji hipotesis yang menggunakan uji-t. Uji hipotesis dilaksanakan dengan taraf signifikansi $5 \%$ dengan kaidah hipotesis $H_{0}$ ditolak apabila $t_{\text {hitung }}>t_{\text {tabel }}$ sedangkan $\mathrm{H}_{0}$ diterima apabila $\mathrm{t}_{\text {hitung }}<\mathrm{t}_{\text {tabel. }}$. Hipotesis yang diuji adalah sebagai berikut.

$\mathrm{H}_{\mathrm{o}}$ : Tidak terdapat perbedaan yang signifikan penguasaan kompetensi pengetahuan IPA antara kelompok siswa yang dibelajarkan melalui model pembelajaran Team Games Tournament berbantuan media lingkungan dengan kelompok siswa yang dibelajarkan melalui pembelajaran konvensional pada siswa kelas IV SD Gugus Untung Surapati tahun ajaran 2019/2020.

Berdasarkan hasil analisis uji-t dari data yang telah diperoleh dari kompetensi pengetahuan IPA siswa diperoleh hasil sebagai berikut.

Tabel 5. Hasil Analisis Uji-t Data Posttest

\begin{tabular}{lcccccccc}
\hline No & Sample & Rata-rata & varians & Dk & $\mathrm{N}$ & $\mathrm{t}_{\text {hitung }}$ & $\mathrm{t}_{\text {tabel }}$ & Kesimpulan \\
\hline 1 & SDN 4 & 83.889 & 47.016 & & 36 & & & \\
& Sumerta & & & & & & & \\
2 & SDN 11 & 73.000 & 81.135 & 72 & 38 & & 1.993 & $\mathrm{H}_{0}$ ditolak \\
& Sumerta & & & & & & & \\
\hline
\end{tabular}

Berdasarkan hasil perhitungan uji-t diperoleh $\mathrm{T}_{\text {hitung }}=5.750$ dan untuk $\mathrm{t}_{\text {tabel }}=1.993$ dan untuk taraf signifikasi $5 \%$ dengan $\mathrm{dk}=72$ diperoleh $t_{\text {tabel }}=1.993$. Dengan demikian nilai $t_{\text {hitung }}>t_{\text {tabel }}$ yakni $5.750>$ 1.993 sehingga Ho ditolak.

Dari hasil analisis data kompetensi pengetahuan IPA dapat diketahui bahwa kedua kelompok yang awalnya memiliki kemampuan setara, lalu setelah diberikan perlakuan yang berbeda, kompetensi pengetahuan IPA siswa pada kelompok eksperimen lebih tinggi jika dibandingkan dengan kompetensi pengetahuan IPA siswa pada kelompok kontrol. Hal tersebut disebabkan oleh belum optimalnya pembelajaran yang diberikan di kelompok kontrol.

Dari penelitian ini membuktikan bahwa model pembelajaran Team Games Tournament berbantuan media lingkungan berpengaruh terhadap kompetensi pengetahuan IPA siswa. Dalam proses pelaksanaan pembelajaran guru harus memiliki kemampuan dalam mengelola kelas, menggunakan media yang sesuai dengan materi maka pelaksanaan pembelajaran berlangsung secara aktif sehingga berdampak pada kompetensi pengetahuan siswa. Model pembelajaran Team Games Tournament berbantuan media lingkungan mengajak siswa belajar di halaman sekolah, kemudian guru membagi siswa menjadi beberapa kelompok berdasarkan prestasi siswa, jenis kelamin, etnik, dan ras. Siswa mengambil kartu soal yang disediakan dengan media lingkungan. Kemudian siswa mengikuti pertandingan yang dilakukan dengan pergeseran tempat duduk. Guru menghitung skor yang dimiliki oleh masing-masing kelompok untuk menetukan pemenang dan masing-masing kelompok mendapatkan reward. Berbeda dengan pembelajaran yang dilaksanakan oleh kelas kontrol, pembelajaran yang diterapkan kurang bervariasi, yang menyebabkan siswa merasa cepat bosan dan kurang aktif pada saat pembelajaran. Sehingga kelompok eksperimen yang mengikuti pembelajaran dengan model pembelajaran Team Games Tournament berbantuan media lingkungan, memperoleh nilai rata-rata yang lebih tinggi jika dibandingkan dengan kelompok kontrol yang diterapkan pembelajaran konvensional.

Model ini membuat siswa lebih bersemangat dalam proses pembelajaran dan pembelajaran menjadi lebih bermakna. Hal itu karena di dalam penerapan model pembelajaran Team Games Tournament menekankan kepada siswa untuk membangun pengetahuannya sendiri melalui kegiatan percobaan. Pembelajaran akan menjadi lebih menyenangkan, jika siswa dirangsang untuk aktif 
mengamati, menyesuaikan antara teori dengan kenyataan serta mempraktekkannya sendiri karena siswa akan dapat mengalami secara langsung proses pembelajarannya terkait dengan materi yang dipelajari. Wildan (2018) menyatakan bahwa Model Team Game Tournament (TGT) adalah bentuk pembelajaran dengan cara siswa belajar dan bekerja dalam kelompok-kelompok kecil secara kolaboratif yang anggotanya terdiri dari empat sampai enam orang dengan struktur kelompok yang bersifat heterogen. Berdasarkan hal tersebut, pembelajaran dengan menggunakan model ini akan melatih siswa serta menumbuhkan keinginan siswa untuk belajar. Selain itu, model pembelajaran Team Games Tournament ini akan mampu menumbuhkan rasa percaya diri siswa itu sendiri sehingga pengetahuan dan pemahaman siswa pun mengenai materi akan lebih mudah diterima. Kurniawan (2019) menyatakan bahwa model team games tournament adalah salah satu model tipe cooperative yang mudah diterapkan dimana melibatkan aktivitas seluruh siswa sebagai pusat pembelajaran. Menurut Fikoyati (2018) mengungkapkan model Team Games Tournament dilaksanakan dengan turnamen akademik, serta berisi berbagai macam pertanyaan atau kuis dan sistem penilaian atau skor, yang dimana siswa bersaing sebagai wakil dari kelompok mereka dengan anggota kelompok lainnya yang kemampuan akademiknya setara. Sedangkan Sugiantara (2017) berpendapat bahwa media lingkungan merupakan segala hal yang terdapat di alam yang dapat digunakan dan tentunya memiliki makna sehingga berpengaruh terhadap setiap manusia. Maka daripada itu model pembelajaran Team Games Tournament berbantuan media lingkungan dapat meningkatkan kompetensi pengetahuan IPA siswa. Kompetensi pengetahuan merupakan perubahan yang terjadi pada segi pengetahuan setelah mendapatkan pembelajaran. Selain itu Kosasih (dalam Adnyana 2017) berpendapat bahwa Kompetensi pengetahuan juga disebut sebagai ranah kognitif yang mengukur pengetahuan siswa yang di dalamnya terdapat 6. Maka dari itu dengan menggunakan model Team Games Tournament berbantuan media lingkungan siswa dapat bersaing sebagai wakil dari kelompok mereka dengan anggota kelompok lainnya.

Selain itu, Tarigan (dalam Oktarianingsih 2019) menyatakan bahwa keunggulan model Team Games Tournament adalah adanya turnament akademik dalam proses pembelajaran. Dimana setiap anggota kelompok mewakili kelompoknya untuk melakukan turnament. Dengan adanya turnament akademik dalam proses pembelajaran dapat mengakibatkan siswa menjadi merasa senang pada saat pelajaran berlangsung karena terdapat permainan yang berupa tournament pada model ini. Azizah (2018) menyatakan bahwa dalam kelas kooperatif Team Game Tournament siswa memiliki kebebasan untuk berinteraksi dan menggunakan pendapatnya. Jadi siswa lebih aktif dalam pembelajaran, rasa percaya diri siswa lebih tinggi, motivasi belajar siswa bertambah, pemahaman belajar lebih mendalam terhadap pokok bahasan. Sedangkan keunggulan media lingkungan menurut Erviana (2015) Keuntungan memanfaatkan media lingkungan antaralain; (1) Menghemat biaya, karena memanfaatkan benda-benda yang telah ada di lingkungan, (2)Memberikan pengalaman yang riil kepada siswa, pelajaran menjadi lebih konkrit, tidak verbalistik, (3) Karena benda-benda tersebut berasal dari lingkungan siswa, maka bendabenda tersebut akan sesuai dengan karakteristik dan kebutuhan siswa (4) Pelajaran lebih aplikatif, materi belajar yang diperoleh siswa melalui media lingkungan kemungkinan besar akan dapat diaplikasikan langsung, karena siswa akan sering menemui benda-benda atau peristiwa serupa dalam kehidupannya sehari-hari, (5) Media lingkungan memberikan pengalaman langsung kepada siswa, (6) siswa dapat berinteraksi secara langsung dengan benda, lokasi atau peristiwa sesungguhnya secara alamiah, (7) Lebih komunikatif,sebab benda dan peristiwa yang ada dilingkungan siswa biasanya mudah dicerna oleh siswa, dibandingkan dengan media yang dikemas (didesain).

Penelitian Kumala (2017) menyatakan terdapat perbedaan yang signifikan kompetensi pengetahuan IPA antara siswa yang dibelajarkan dengan model Team Games Tournament dengan siswa yang dibelajarkan secara konvensional. Candra (2017) juga menyatakan model pembelajaran tipe Team Game Tournament berbantuan peta konsep berpengaruh terhadap kompetensi pengetahuan IPA siswa kelas IV SD gugus Letda Made Putra. Selain itu hasil penelitian ini juga didukung berdasarkan penelitian yang dilaksanakan oleh Cahyaningsih (2017) bahwa berdasarkan hasil uji pengolahan data dengan uji-t dan temuan dalam penelitian dapat disimpulkan bahwa ada pengaruh model pembelajaran kooperatif tipe TGT terhadap hasil belajar matematika aspek kognitif dan psikomotor.

Hasil penelitian menunjukkan bahwa rata-rata kompetensi pengetahuan IPA pada kelompok eksperimen adalah 83.889 sedangkan rata-rata pada kelompok kontrol adalah 73.000. Setelah dilakukan uji hipotesis menggunakaan uji $\mathrm{t}$ dengan rumus polled varians, diperoleh $t_{\text {hitung }}=5.750$ dan untuk $t_{\text {tabel }}=$ 1.993 dan untuk taraf signifikasi 5\% dengan $\mathrm{dk}=72$ diperoleh $\mathrm{T}_{\text {tabel }}=1.993$. Dengan demikian nilai $\mathrm{t}_{\text {hitung }}>$ $t_{\text {tabel }}$ yakni $5.750>1.993$ sehingga Ho ditolak. Hal ini berarti terdapat perbedaan yang signifikan kompetensi pengetahuan IPA antara kelompok siswa yang mengikuti pembelajaran melalui model pembelajaran Team Games Tournament berbantuan media lingkungan dengan kelompok siswa yang mengikuti pembelajaran konvensional pada siswa kelas IV di SD Gugus Untung Surapati Tahun Ajaran $2019 / 2020$. 
Penelitian ini diperkuat oleh simpulan yang telah disampaikan oleh Prawiti (2018) yang mengatakan rerata kompetensi siswa yang dibelajarkan dikelas eksperimen dengan menggunakan model Team Games Tournament lebih tinggi dibandingkan di kelas kontrol. Selain itu, Darmawati (2016) juga mengatakan terdapat perbedaan yang signifikan siswa yang dibelajarkan menggunakan model Team Games Tournament dengan setting lingkungan dibandingkan siswa yang dibelajarkan secara konvensional. Dengan demikian, model pembelajaran Team Games Tournament berbantuan media lingkungan pengaruh terhadap kompetensi pengetahuan IPA siswa kelas IV di SD Gugus Untung Surapati Tahun Ajaran $2019 / 2020$.

\section{KESIMPULAN}

Berdasarkan hasil analisis data yang telah diaksanakan maka dapat disimpulkan bahwa terdapat pengaruh yang signifikan model pembelajaran Team Games Tournament berbantuan media lingkungan terhadap kompetensi pengetahuan IPA siswa kelas IV SD Gugus Untung Surapati 2019/2020. Berdasarkan hasil penelitian ini maka saran dapat disampaikan kepada pihak-pihak terkait sebagai berikut. Kepada kepala sekolah disarankan dapat dijadikan bahan kebijakan dalam meningkatkan kualitas pembelajaran IPA yang dilaksanakan oleh guru-guru dan dapat memfasilitasi segala aktivitas belajar siswa. Kepada guru disarankan supaya menggunakan model ini sebagai model pilihan unutk melakukan perbaikan pembelajaran. Kepada peneliti lain disarankan dapat mengembangkan model penelitian ini dan mengaitkannya dengan mata pelajaran lain, sehingga nantinya dapat menambah ilmu pengetahuan.

\section{DAFTAR PUSTAKA}

Adnyana. 2017. "Pengaruh Model Pembelajaran Kooperatif Tipe Talking Stick Terhadap Kompetensi Pengetahuan IPA". Volume 5 No. 3 Tahun 2017. Jurusan Pendidikan Guru Sekolah Dasar Universitas Pendidikan Ganesha." Mimbar $\quad$ PGSD $\quad$ Undiksha 5 (3). https://doi.org/http://dx.doi.org/10.23887/jjpgsd.v5i3.12426.

Agung, A. A. Gede. 2014. Metodologi Penelitian Pendidikan. Malang: Aditya Media Publishing.

Agustini, Md. 2014. "Pengaruh Model Pembelajaran TGT Berbantuan Media Flip Chart Terhadap Hasil Belajar IPA Siswa Kelas V SD." Mimbar PGSD Undiksha 2 (1). https://doi.org/http://dx.doi.org/10.23887/jjpgsd.v2i1.3097.

Arikunto, Suharsimi. 2016. Dasar-Dasar Evaluasi Pendidikan. Jakarta: Bumi Aksara.

Arikunto, Suharsimi. 2018. Dasar-Dasar Evaluasi Pendidikan. Jakarta: Bumi Aksara.

Azizah, Nur. 2018. "Pengaruh Model TGT Berbantu Media Utama Terhadap Hasil Belajar Matematika Ditinjau Dari Aktivitas Belajar Siswa Kelas V SD.” Jurnal Sekolah 2 (4). https://doi.org/ps://doi.org/10.24114/js.v2i4.10682.

Baktini, Wulan. 2019. "Pengaruh Model Teams Games Tournament Dan Student Team Achievement Division Terhadap Hasil Belajar IPA Di Sekolah Dasar." Jurnal Pendidikan Dasar Indonesia 4 (1): 2428. https://doi.org/http://dx.doi.org/10.26737/jpdi.v4i1.943.

Cahyaningsih, Ujiati. 2017. "Pengaruh Model Pembelajaran Kooperatif Tipe Team Games Tournament (TGT) Terhadap Hasil Belajar Matematika Siswa SD." Jurnal Cakrawala Pendas 3 (2). https://media.neliti.com/media/publications/280142-pengaruh-model-pembelajaran-kooperatift-7be45d50.pdf.

Candra, Yuni. 2017. "Pengaruh Model Pembelajaran Kooperatif Tipe Teams Games Tournament Berbantuan Peta Konsep Terhadap Kompetensi Pengetahuan IPA Siswa Kelas IV SD Gugus Letda Made Putra." Mimbar $\quad$ PGSD $\quad$ Undiksha 55 (2). https://doi.org/http://dx.doi.org/10.23887/jjpgsd.v5i2.10658.

Dantes, Nyoman. 2017. "Penerapan Model Pembelajaran Kooperatif Tipe TGT Dengan Media Kartu Kata Untuk Meningkatkan Motivasi Belajar Dan Kemampuan Membaca." International Journal of Elementary Education 1 (1): 19-28. https://doi.org/http://dx.doi.org/10.23887/ijee.v1i1.11435. 
Darmadi, Hamid. 2014. Metode Penelitian Pendidikan Sosial. Bandung: Alfabeta.

Darmawati, D. 2016. "Pengaruh Model Pembelajaran Kooperatif Tipe Team Games Tournament (TGT) Dan Aktivitas Setting Lingkungan Terhadap Hasil Belajar Siswa Dalam Mata Pelajaran IPA Kelas IV SD Negeri 002 Rambah Kabupaten Rokan Hulu." Jurnal Ilmiah Edu Research 5 (1). https://pdfs.semanticscholar.org/af77/564b2590a808fd436c6e46ab36da735c5663.pdf.

Erviana, Lina. 2015. "Pemanfaatan Media Pembelajaran Berbasis Lingkungan Sebagai Sarana Praktikum IPA Untuk Meningkatkan Pemahaman Konsep Siswa Di SMP-It Ar Rahmah Pacitan." Jurnal Dinamika Pendidikan Dasar 7 (2): 71-77. https://doi.org/0.30595/dinamika.v7i2.936.

Fikoyati, M.R. 2018. "Pengaruh Model Pembelajaran Team Games Tournament Berbantuan Media TTS Terhadap Hasil Belajar IPA Pada Siswa Kelas III SD." Jurnal Sekolah 2. https://doi.org/https://doi.org/10.24114/js.v2i3.9917.

Hakim, Syifa Aulia. 2017. "Pengaruh Model Pembelajaran Kooperatif Tipe Teams Games Tournament (TGT) Terhadap Motivasi Belajar IPA Di Kelas IV SDN Kelapa Dua 06 Pagi Jakarta Barat." International Journal of Elementary Education 1 (4): 249-63. https://doi.org/http://dx.doi.org/10.23887/ijee.v1i4.12966.

Hamzah. 2012. Belajar Dengan Pendekatan P A I L K E M. Jakarta: Bumi Aksara.

Japa, I Gusti Ngurah. 2017. "Penerapan Pembelajaran Kontekstual Dengan Mengintensifkan Tutor Sebaya Dan Media Lingkungan Sebagai Upaya Peningkatan Prestasi Belajar IPA." International Journal of Elementary Education 1 (2): 125-28. https://doi.org/http://dx.doi.org/10.23887/ijee.v1i2.11604.

Karini, Ni Wayan. 2020. "Pengaruh Model Pembelajaran TGT (Teams Games Tournament) Dengan Seting Lesson Study Terhadap Sikap Ilmiah Siswa." Indonesian Journal Of Educational Research And Review 3 (1). https://doi.org/http://dx.doi.org/10.23887/ijerr.v3i1.24881.g15111 Refbacks.

Adnyana. 2017. "Pengaruh Model Pembelajaran Kooperatif Tipe Talking Stick Terhadap Kompetensi Pengetahuan IPA". Volume 5 No. 3 Tahun 2017. Jurusan Pendidikan Guru Sekolah Dasar Universitas Pendidikan Ganesha." Mimbar PGSD Undiksha 5 (3). https://doi.org/http://dx.doi.org/10.23887/jjpgsd.v5i3.12426.

Agung, A. A. Gede. 2014. Metodologi Penelitian Pendidikan. Malang: Aditya Media Publishing.

Agustini, Md. 2014. "Pengaruh Model Pembelajaran TGT Berbantuan Media Flip Chart Terhadap Hasil Belajar IPA Siswa Kelas V SD." Mimbar PGSD Undiksha 2 (1). https://doi.org/http://dx.doi.org/10.23887/jjpgsd.v2i1.3097.

Arikunto, Suharsimi. 2016. Dasar-Dasar Evaluasi Pendidikan. Jakarta: Bumi Aksara.

Arikunto, Suharsimi. 2018. Dasar-Dasar Evaluasi Pendidikan. Jakarta: Bumi Aksara.

Azizah, Nur. 2018. "Pengaruh Model TGT Berbantu Media Utama Terhadap Hasil Belajar Matematika Ditinjau Dari Aktivitas Belajar Siswa Kelas V SD." Jurnal Sekolah 2 (4). https://doi.org/ps://doi.org/10.24114/js.v2i4.10682.

Baktini, Wulan. 2019. "Pengaruh Model Teams Games Tournament Dan Student Team Achievement Division Terhadap Hasil Belajar IPA Di Sekolah Dasar." Jurnal Pendidikan Dasar Indonesia 4 (1): 2428. https://doi.org/http://dx.doi.org/10.26737/jpdi.v4i1.943.

Cahyaningsih, Ujiati. 2017. "Pengaruh Model Pembelajaran Kooperatif Tipe Team Games Tournament (TGT) Terhadap Hasil Belajar Matematika Siswa SD." Jurnal Cakrawala Pendas 3 (2). https://media.neliti.com/media/publications/280142-pengaruh-model-pembelajaran-kooperatift-7be45d50.pdf.

Candra, Yuni. 2017. "Pengaruh Model Pembelajaran Kooperatif Tipe Teams Games Tournament Berbantuan Peta Konsep Terhadap Kompetensi Pengetahuan IPA Siswa Kelas IV SD Gugus Letda 
Made $\quad$ Putra."
https://doi.org/http://dx.doi.org/10.23887/jjpgsd.v5i2.10658.

$(2)$.

Dantes, Nyoman. 2017. "Penerapan Model Pembelajaran Kooperatif Tipe TGT Dengan Media Kartu Kata Untuk Meningkatkan Motivasi Belajar Dan Kemampuan Membaca." International Journal of Elementary Education 1 (1): 19-28. https://doi.org/http://dx.doi.org/10.23887/ijee.v1i1.11435.

Darmadi, Hamid. 2014. Metode Penelitian Pendidikan Sosial. Bandung: Alfabeta.

Darmawati, D. 2016. "Pengaruh Model Pembelajaran Kooperatif Tipe Team Games Tournament (TGT) Dan Aktivitas Setting Lingkungan Terhadap Hasil Belajar Siswa Dalam Mata Pelajaran IPA Kelas IV SD Negeri 002 Rambah Kabupaten Rokan Hulu." Jurnal Ilmiah Edu Research 5 (1). https://pdfs.semanticscholar.org/af77/564b2590a808fd436c6e46ab36da735c5663.pdf.

Erviana, Lina. 2015. "Pemanfaatan Media Pembelajaran Berbasis Lingkungan Sebagai Sarana Praktikum IPA Untuk Meningkatkan Pemahaman Konsep Siswa Di SMP-It Ar Rahmah Pacitan." Jurnal Dinamika Pendidikan Dasar 7 (2): 71-77. https://doi.org/0.30595/dinamika.v7i2.936.

Fikoyati, M.R. 2018. "Pengaruh Model Pembelajaran Team Games Tournament Berbantuan Media TTS Terhadap Hasil Belajar IPA Pada Siswa Kelas III SD.” Jurnal Sekolah 2. https://doi.org/https://doi.org/10.24114/js.v2i3.9917.

Hakim, Syifa Aulia. 2017. "Pengaruh Model Pembelajaran Kooperatif Tipe Teams Games Tournament (TGT) Terhadap Motivasi Belajar IPA Di Kelas IV SDN Kelapa Dua 06 Pagi Jakarta Barat." International Journal of Elementary Education $1 \quad$ (4): 249-63. https://doi.org/http://dx.doi.org/10.23887/ijee.v1i4.12966.

Hamzah. 2012. Belajar Dengan Pendekatan P A I L KE M. Jakarta: Bumi Aksara.

Japa, I Gusti Ngurah. 2017. "Penerapan Pembelajaran Kontekstual Dengan Mengintensifkan Tutor Sebaya Dan Media Lingkungan Sebagai Upaya Peningkatan Prestasi Belajar IPA." International Journal of Elementary Education 1 (2): 125-28. https://doi.org/http://dx.doi.org/10.23887/ijee.v1i2.11604.

Karini, Ni Wayan. 2020. "Pengaruh Model Pembelajaran TGT (Teams Games Tournament) Dengan Seting Lesson Study Terhadap Sikap Ilmiah Siswa." Indonesian Journal Of Educational Research And Review 3 (1). https://doi.org/http://dx.doi.org/10.23887/ijerr.v3i1.24881.g15111 Refbacks.

Kumala, Dara. 2017. "Pengaruh Model Pengaruh Model Pembelajaran Kooperatif Tipe Team Games Tournament Terhadap Penguasaan Kompetensi Pengetahuan IPA." Mimbar PGSD Undiksha 5 (2). https://doi.org/http://dx.doi.org/10.23887/jjpgsd.v5i2.10802.

Kurniawan, Bayu. 2019. "Pengaruh Model TGT Berbantu Media Pinball Terhadap Hasil Belajar Siswa." International Journal of Elementary Education 3 (1): 23-28. https://doi.org/http://dx.doi.org/10.23887/ijee.v3i1.17280.

Kusumaningrum, Putu Citra Arni. 2014. “Pengaruh Model Pembelajaran Kooperatif Tipe Team Games Tournament (TGT) Terhadap Hasil Belajar IPA Pada Siswa Kelas V Gugus XV Kecamatan Buleleng Tahun Ajaran 2013/2014." Mimbar PGSD Undiksha 2 (1). https://ejournal.undiksha.ac.id/index.php/JJPGSD/article/view/4532.

Oktarianingsih, Luh. 2019. "Pengaruh Model Pembelajaran Team Games Tournament Berbantuan Media Visual Terhadap Kompetansi Pengetahuan IPA." Jurnal Penelitian Dan Pengembangan Pendidikan 3 (3). https://doi.org/http://dx.doi.org/10.23887/jppp.v3i3.18609.

Prameswari, Kd Krisna. 2017. "Pengaruh Model Pembelajaran Course Review Horay (CRH) Berbantuan Media Lingkungan Sekolah Terhadap Kompetensi Pengetahuan IPA Siswa Kelas V SD Gugus Kompyang Sujana Kecamatan Denpasar Utara." Mimbar PGSD Undiksha 5 (2). https://doi.org/http://dx.doi.org/10.23887/jjpgsd.v5i2.11001. 
Prawiti, A.E. 2018. "Pengaruh Model Team Games Tournament Terhadap Prestasi Belajar IPA Siswa Kelas V SD Negeri Gedongtengen Yogyakarta Tahun Ajaran 2016/2017." http://jurnal.ustjogja.ac.id/index.php/trihayu/article/view/2239.

Samatowa, Ahmad. 2016. Pembelajaran IPA Di SD. Jakarta: PT. Indeks.

Setiadi, Zulfa. 2019. "Pengaruh Model TGT Media Dakonmatika Materi FPB \& KPK Terhadap Hasil Belajar." International Journal of Elementary Education $3 \quad$ (4): 501-10. https://doi.org/http://dx.doi.org/10.23887/ijee.v3i4.22560.

Sudamayanto, Komang. 2014. "Penerapan Model Pembelajaran Kooperatif Tipe Team Game Tournament Berbantuan Media Gambar Untuk Meningkatkan Hasil Belajar IPA Siswa Kelas V SD N 1 Mundeh Kangin." Mimbar
https://ejournal.undiksha.ac.id/index.php/JJPGSD/article/view/4342.

Sugiantara, dkk. 2017. "Pengaruh Model Pembelajaran TTW Berbantuan Media Lingkungan Terhadap Penguasaan Kompetensi Pengetahuan IPA Siswa Kelas IV.” Mimbar PGSD Undiksha 1 (3): 1-10. https://doi.org/http://dx.doi.org/10.23887/jjpgsd.v5i2.10764.

Sugiyono. 2016. Metode Penelitian Kuantitatif Dan Kualitatif Dan R\&D. Bandung: PT Alfabeta.

Susanto, Ahmad. 2012. Teori Belajar Dan Pembelajaran Di Sekolah Dasar. Jakarta: Prenamedia Group.

Wahyuni, Kd Mita. 2014. "Pengaruh Model Pembelajaran Team Game Turnament (TGT) Melalui Variasi Reinforcement Terhadap Hasil Belajar IPS Siswa Kelas V SD Gugus III Batuan Sukawati Tahun Pelajaran 2013/2014." Mimbar PGSD Undiksha 2 (1). https://doi.org/http://dx.doi.org/10.23887/jjpgsd.v2i1.3205.

Wildan, Yanuar Khoirul. 2018. "Pengaruh Model Pembelajaran Kooperatif Learning Type Team Game Tournament Pada Mata Pembelajaran IPA Terhadap Motivasi Belajar Siswa Kelas V SD Negeri 04 Tlagasana Pemalang." SENDIKA.

Wulandari, Sry. 2018. “Upaya Meningkatkan Keaktifan Belajar Siswa Melalui Model Pembelajaran Kooperatif Tipe Team Game Tournament (TGT) Dengan Media Teka Teki Silang (TTS) Pada Mata Pelajaran IPA DI Kelas IV SDN 101816 Pancur Batu TA 2017/2018." UNIMED. http://digilib.unimed.ac.id/id/eprint/35039. 